\title{
Döviz Kuru Oynaklığı ve Karşılaştırmalı Faiz Oranları: Türkiye'de Sermaye Akışları ve Yerleşiklerin Dolarizasyon Eğilimlerini Belirleyen Faktörler
}

\author{
Tuna Can Güleça
}

\section{Özet}

Bu çalışmada, Türkiye'de döviz kurunda meydana gelen oynaklık şoklarının, yerleşiklerin dolarizasyon eğilimi ve sermaye akışları üzerinde yarattığı etkiler ele alınmıştır. Döviz kurlarına dair oynaklık serileri, EGARCH modeli kullanılarak türetilmiştir. Döviz kurlarındaki oynaklığın sermaye akımları ve dolarizasyona etkilerinin, ayrı hem uzun hem de kısa vadede modellenmesi amacıyla, sınırlandırılmamış hata düzeltme süreci ile yürütülen ARDL yöntemi kullanılmıştır. Ayrıca, faiz politikalarındaki değişimlerin tespit edilmesi amacıyla, ilgili yabancı para birimlerinin faiz oranları da kurulan modellere eklenmiştir. Elde edilen bulgulara göre, dolarizasyon eğilimi ve sermaye akışları üzerinde, döviz kuru oynaklığının etkileri hem uzun hem de kısa vadede oldukça sınırlıdır. Faiz politikalarının ise ilgili değişkenler üzerinde kısa vadede oldukça güçlü bir etkiye sahip olduğu gözlenmektedir. Uzun vadede bu ilişkinin kuvveti daha da artmaktadır. Döviz kuru oynaklığının yüksek seviyelerde seyrettiği dönemlerde dahi, karşılaştırmalı faiz oranlarının dolarizasyon ve sermaye akışları üzerinde, döviz kuru oynaklığına oranla çok daha etkili olması, yerleşiklerin ve yatıımcıların parasal kararlarında büyük ölçüde dürtüsel davranmadığına işaret etmektedir.
Anahtar Kelimeler

Dolarizasyon

Döviz Kuru Oynaklığı

ARDL

GARCH

Makale Hakkında

Geliş Tarihi: 01.10.2019

Kabul Tarihi: 24.04.2020

Doi: 10.18026/cbayarsos.628072

\section{Exchange Rate Volatility and Comparative Interest Rates: The Determinants of Capital Flows and Resident Dollarization in Turkey}

\begin{abstract}
In this study, the effects of the volatility shocks in the exchange rate on the resident dollarization and the net capital flows are discussed. The volatility of the exchange rate is derived using EGARCH model. ARDL method is used to model the effects of foreign exchange rate volatility on capital flows and dollarization in the long and short term. Additionally, the interest rate series of the relevant foreign currencies have been added to the model to represent the influence of the changes in the interest rate policies in this context. Findings indicate that, in terms of influencing capital flows and resident dollarization, interest rate policies have a significant effect in the short-run while having an even stronger effect in the long run. Additionally, exchange rate shocks have been found to have a limited effect on capital outflows and resident dollarization. Results suggest that the decision making process of investors and residents is not impulsive and even during the periods of excessive exchange rate volatility, the capital outflows and the resident dollarization are significantly more affected by interest rate changes than exchange rate shocks.
\end{abstract}

Keywords

Dollarization

Exchange Rate Volatility

GARCH

ARDL

\section{About Article}

Received: 01.10.2019

Accepted: 24.04 .2020

Doi: 10.18026/cbayarsos.628072

a İletişim Yazarı: tunacan.gulec@cbu.edu.tr 


\section{Introduction}

The most fundamental rule of finance is that the risk should always be appropriately compensated with higher returns. This rule is as valid in macroeconomics as in individual financial decision making. Perception of risk is the main determinant of the interest rates and the exchange rate volatility is one of the main determinants of the perception of risk when it comes to evaluating international investments that are subject to exchange rate risks. In 2018 Turkey has faced a period of excessive exchange rate volatility. Coupled with political risk factors, this volatility has also resulted in a loss of value in the long term for the Turkish Lira.

According to the reports of the Central Bank of The Republic of Turkey, the forex deposits by the residents are nearly doubled since last 6 years. In the following period, Turkish Lira has significantly lost its value against foreign currencies along with the increasing interest rates, inflation, and unemployment. While the role of political risks is surely significant for this period, the main focus of this study is on the role of exchange rate shocks. Exchange rate shocks are defined as a period with excessively high fluctuations in the exchange rate.

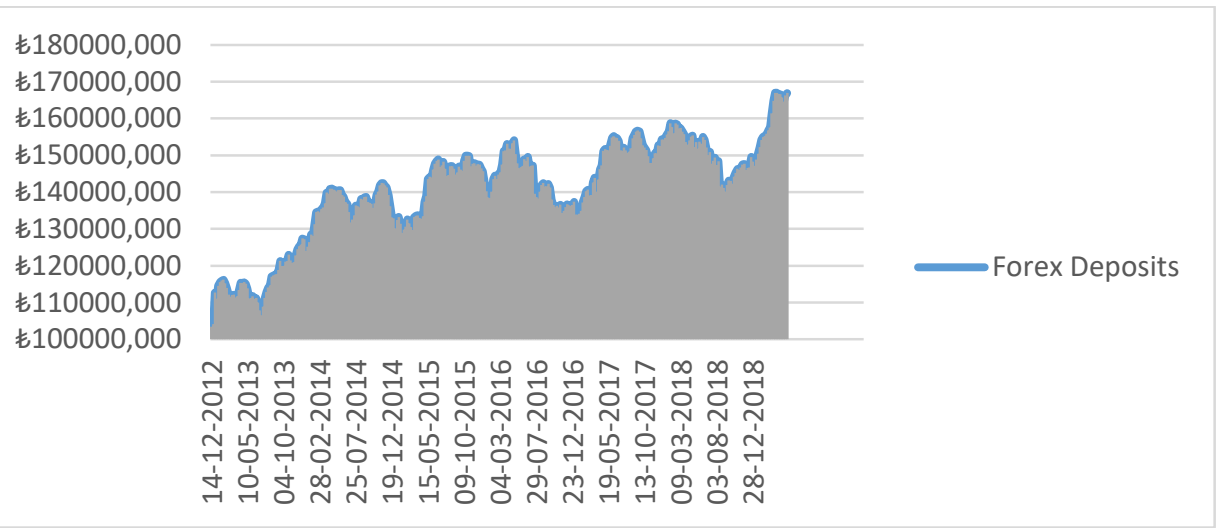

Figure 1. Forex Deposits of Residents (CBRT - Financial Accounts Report)

Periods of excessive volatility in the exchange rate are usually prone to manipulation and may lead to events such as a simultaneous rise in both domestic interest rates and the value of foreign currency. These short term inefficiencies, however, cannot exist in the long run and are usually arbitraged in the market in the long run. An overwhelming majority of studies in the literature suggests using the volatility of exchange rate series instead of its base level as the independent variable. Therefore, in this study, volatility series are created using EGARCH model. Then accordingly, an unrestricted ARDL error correction model is constructed to best reflect the long term and short term effects of exchange rate volatility on dollarization and capital flows.

\section{Literature Review}

Exchange rate shocks, interest rates, capital flows, and dollarization are topics well-structured in the literature and are almost as old as the field of economics itself. Therefore, in the literature review, I discuss the approaching literature that is closely related to the analyses concluded in the study.

Unpredictability is the main reason for economic disruption in most of the economic crises. A constant level of chronic inflation in an economy is less destructive than an instant one because it creates a type of uncertainty that can be best described as ambiguity. The fundamental principle of finance is about taking calculated risks. In an unpredictably ambiguous 
environment, calculating the risk is not possible. The studies that take the effect of exchange rate volatility into account almost unanimously agree on the inverse relationship between the volatility of exchange rate and financial stability.

In a study that uses similar analysis methods to mine, Bahmani et.al. (2018). have used linear models to analyze the effects of the changes in Turkish Lira on domestic production of Turkey. Using asymmetry analysis, and ARDL approach by Shin et. Al. (2014), they find evidence that both the appreciation and depreciation of lira contributes to domestic production.

In an effort to reveal the determinants of USD/TRY exchange rate, a recent study (2018) has used multivariate adaptive regression splines method on a 28-year quarterly time-series data. Study finds evidence of an inverse relationship between the value of USD and current account deficit. In other words, as the current account yields negative figures (deficit), the value of USD increases. Additionally, findings of the study indicate that, as the Gross Domestic Product (GDP)growth rate increases, TRY appreciates.

With the purpose of determining the sources of fluctuations in the exchange rates, Lastrapes (1992) decomposes exchange rate fluctuations as real and as nominal fluctuations under 2 categories. The distinction between real and nominal exchange rates is obtained by determining if the shock has a permanent(long-term) effect or not. The shocks that a temporary are categorized as nominal while the shock that has long term or permanent effects are categorized as real. The study discusses that real shocks have much stronger implications on the market. In this analysis, the exchange rate shocks that occurred in 2018 can be categorized as real under these terms due to their long term significant effects on capital flows and dollarization.

The study of Farrant and Peersman (2006), further discusses the relationship between real exchange rate and the nominal exchange rate using the structural vector auto-regression model. Comparing their findings to a benchmark conventional study (Clarida \& Gali, 1994), they determine that the real exchange rate is a source of shock in the economy by itself instead of being a shock absorber. Similarly, while discussing the 2001 economic crisis in Turkey, Rossi and Leigh(2002) find that there is a strong correlation between the exchange rate and the domestic price levels in Turkey. It is also discussed in the book that the exchange rate and dollarization has a strong correlation in Turkey as well. For foreign investors, it is pointed out in the book that the volatility in the exchange rate may be a significant risk factor without the usage of derivatives.

In an attempt to analyze the components of the fluctuations in real exchange rate, Clarida and Gali (1994) have analyzed four countries. For Germany and Japan, the study finds that shocks to money supply explain a substantial portion of the real exchange rate movements. Additionally, the study finds that demand shocks significantly affects the market prices while supply shocks are largely ineffective.

A study that investigates the relationship between the volatility of the exchange rate and dollarization focuses on the African economies(Mengesha \& Holmes, 2013). The study uses EGARCH analysis to model the volatility of exchange rates in an 11-year period. According to the results of the study, dollarization has a positive impact on the real exchange rate volatility. The study, however, does not include a causality test which may indicate that results may be interpreted in vice versa direction. In this case, the increased volatility in the real exchange rate may be a cause of increased dollarization of deposits trend. A similar study was made for the 
case of Cambodia using the GARCH analysis(Lay, Kakinaka, \& Kotani, 2012). Findings of the study indicate that in Cambodia, dollarization has a positive correlation with the volatility of the exchange rate. While findings are in line with the literature, the study also argues that dollarization is a source of poverty by itself due to the enforced uncertainty in everyday prices.

Another significant study on the determinants of financial dollarization provides evidence that dollarization has an over-estimated positive effect in the short run, however, in practice, its positive effects are significantly lower. In addition to that, the main reason for observed short term dollarization is argued to be mainly caused by the banks. Findings of the study also indicate that a deviation in terms of volatility in the interest rate is a cause for both short and long term dollarization(Neanidis \& Savva, 2009).

\section{Methodology}

\section{Dataset}

The dataset consists of 336 observations in weekly frequency starting from 14-12-2012 to 1705-2019. Series used in the analysis is demonstrated in Table 1. Data is acquired from the electronic data base of CBRT.

Table 1. Explanations of Series Used in The Analysis

\begin{tabular}{lc}
\hline Variable & Explanation \\
\hline dollarization & (Resident Forex Deposits + Forex Transfers)/(Total Deposits) \\
exratevolatility & Conditional Variance Series of EGARCH(1,1) \\
(USD Exchange rate logarithmic returns) & Interest rate of EUR for given date \\
interesteur & Interest rate of TRY for given date \\
interesttry & Interest rate of USD for given date \\
\hline
\end{tabular}

Series are tested for stationarity using ADF and KPSS unit root tests. The first difference of all series except exratevolatility is taken to provide stationarity. Exratevolatility is reported stationary on the level. Results are reported in Table 2.

Table 2. ADF and KPSS Unit Root Test Results

\begin{tabular}{|c|c|c|c|c|}
\hline & \multicolumn{2}{|r|}{ ADF } & \multicolumn{2}{|r|}{ KPSS } \\
\hline & Constant & Constant and Trend & Constant & Constant and Trend \\
\hline dollarization & $-1.4236(0)$ & $-0.8803(0)$ & $0.7335(15)^{* * * * 4}$ & $0.1598(14)^{* * * *}$ \\
\hline$\Delta$ dollarization & $-11.6937(1)^{* * * *}$ & $-11.7763(1)^{* * * *}$ & 0.2403 & $0.1051(4)$ \\
\hline exratevolatility & $-3.3420(16)^{* * * *}$ & $-4.2270(14)^{* * *}$ & $0.3310(14)$ & $0.0416(13)$ \\
\hline interesteur & $-1.8373(14)$ & $-2.6271(14)$ & $1.0852(15)^{* * * *}$ & $0.3518(15)^{* * * *}$ \\
\hline$\Delta$ interesteur & $-3.7847(13)^{* * * * 4}$ & $-3.7881(13)^{* * * *}$ & $0.0660(11)$ & $0.0719(11)$ \\
\hline interesttry & $-0.7738(16)$ & $-2.0159(16)$ & $1.7310(15)^{* * * *}$ & $0.2113(15)^{* * *}$ \\
\hline$\Delta$ interesttry & $-5.3300(15)^{* * * *}$ & $-5.3183(15)^{* * * *}$ & $0.0683(9)$ & $0.0557(9)$ \\
\hline
\end{tabular}




\begin{tabular}{|c|c|c|c|c|c|c|c|c|}
\hline interestusd & \multicolumn{3}{|c|}{$-1.6679(14)$} & $-2.1737(14)$ & \multicolumn{3}{|c|}{$1.1751(15)^{* * * *}$} & $0.3819(15)^{* * * * *}$ \\
\hline$\Delta$ interestusd & \multicolumn{3}{|c|}{$-3.7023(13)^{* * * *}$} & $-3.6836(13)^{* * * * *}$ & \multicolumn{3}{|c|}{$0.1067(8)$} & $0.0858(8)$ \\
\hline \multirow[t]{3}{*}{ Critical Values } & $\% 1$ & -3.4513 & $\% 1$ & -3.9878 & $\% 1$ & 0.7390 & $\% 1$ & 0.2160 \\
\hline & $\% 5$ & -2.8706 & $\% 5$ & -3.4243 & $\% 5$ & 0.4630 & $\% 5$ & 0.1460 \\
\hline & $\% 10$ & -2.5717 & $\% 10$ & -3.1352 & $\% 10$ & 0.3470 & $\% 10$ & 0.1190 \\
\hline
\end{tabular}

Note: ${ }^{* * * * * * *}$ represent respectively significance levels at $\% 1, \% 5$ and $\% 10$. Values in the parenthesis show lag length according to unit root tests. $\Delta$ represents the 1 st difference.

\section{Research Model}

Due to the level difference between series exratevolatility $\mathrm{I}(0)$ and other series I(1), ARDL bounds test has been used to search for co-integration. ARDL bounds test analyzes the existence of co-integration among the variables of different levels (Pesaran, Shin, \& Smith, 2001). An unrestricted error correction model has been constructed to be able to search for cointegration with bounds test.

The unrestricted error correction model is expressed as below:

$\Delta$ dollarization $=\beta_{0}+\beta_{1} \sum_{i=1}^{q} \Delta$ dollarization $_{t-i}+\beta_{2} \sum_{i=1}^{q}$ sexratevolatility $_{t-i}+$ $\beta_{3} \sum_{i=1}^{q}$ sinteresteur $+\beta_{4}$ sinteresttry $_{t-i}+\beta_{5} \sum_{i=1}^{q}$ sinterestusd $_{t-i}+\delta_{1}$ dollarization $_{t-i}+$ $\delta_{2}$ exratevolatility $_{t-i}+\delta_{3}$ interesteur $_{t-i}+\delta_{4}$ interesttry $_{t-i}+\delta_{5}$ interestusd $_{t-i}+\varepsilon_{t}$

The null hypothesis regarding the co-integration testing in this equation is:

$H_{0}: \delta_{1}=\delta_{2}=\delta_{3}=\delta_{4}=\delta_{5}=0$

Resulting F statistic is then compared with the high and low values reported in the study of Pesaran et. al. (2001) for $\% 1, \% 5$ and $\% 10$ level of significance. If the F statistic is lower than $\mathrm{I}(0)$, then the hypothesis that claims that there is a co-integration can be rejected. On the other hand, If the F statistic is higher than I(1), then the existence of a co-integration can be argued. Of the reported value of F statistic is between the values of $\mathrm{I}(0)$ and $\mathrm{I}(1)$, no judgment can be made regarding the existence of a co-integration.

Firstly, the optimal lag length has been decided to test for the existence of co-integration with bound test. Optimal lag lengths for equation(1) is demonstrated in Table 3.

Table 3. Bound Test Optimal Lag Length Determination

\begin{tabular}{cccccc}
\hline \multirow{2}{*}{ Lag Count } & $\mathbf{R}^{2}$ & \multicolumn{2}{c}{ JB Test 1 } & \multicolumn{2}{c}{ Breusch-Pagan Test } \\
& & Test Statistic & Prob & Test Statistic & Prob \\
\hline 1 & 0.9536 & 215875.1 & 0.0000 & 1.6370 & 0.1038 \\
2 & 0.9541 & 2168837 & 0.0000 & 1.2399 & 0.2450 \\
3 & 0.9547 & 209623.9 & 0.0000 & 1.0605 & 0.3916 \\
4 & 0.9556 & 197728.1 & 0.0000 & 0.9887 & 0.4810 \\
5 & 0.9560 & 184136.5 & 0.0000 & 1.0003 & 0.4695 \\
\hline Lag Count & Breusch-Godfrey LM Test & AIC & SC & HQ \\
& Test Statistic & Prob & & & -5.8006 \\
\hline 1 & 1.1337 & 0.3231 & -5.8471 & -5.7306 & \\
\hline
\end{tabular}


Exchange Rate Volatility and Comparative Interest Rates: The Determinants of Capital Flows and Resident Dollarization in Turkey

\begin{tabular}{cccccc}
\hline 2 & 1.2924 & 0.2761 & -5.8254 & -5.6496 & -5.75480 .54 \\
3 & 1.3910 & 0.2504 & -5.8057 & -5.5718 & -5.7124 \\
4 & 0.3848 & 0.6809 & -5.7922 & -5.4999 & -5.6752 \\
5 & 0.1023 & 0.9027 & -5.7683 & -5.4158 & -5.6276 \\
\hline
\end{tabular}

Each lag length has been tested using AIC, SC, and HQ information criteria along with Breusch-Godfrey LM autocorrelation and Breusch-Pagan heteroskedasticity tests. As reported in Table 3, the results of the tests suggest that the optimal lag length should be 1 .

With this finding, unrestricted error correction model has been constructed with a lag length of 1 . Table 4 demonstrates the bound test F-statistics for the null hypothesis of co-integration relationship $H_{0}: \delta_{1}=\delta_{2}=\delta_{3}=\delta_{4}=\delta_{5}=0$ ).

Table 4. Bound Test Results

\begin{tabular}{|c|c|c|c|c|c|c|}
\hline \multicolumn{7}{|c|}{ Model 1 Constant Long Term } \\
\hline & \multicolumn{2}{|c|}{ Lag Count } & \multicolumn{2}{|c|}{ F Statistic } & & \\
\hline & \multicolumn{2}{|c|}{1} & \multicolumn{2}{|c|}{4.82} & & \\
\hline \multicolumn{7}{|c|}{ Pesaran Table Values } \\
\hline & \multicolumn{2}{|c|}{ \%10 Level of Significance } & \multicolumn{2}{|c|}{ \%5 Level of Significance } & \multicolumn{2}{|c|}{ \%1 Level of Significance } \\
\hline K & $\mathrm{I}(0)$ & $\mathrm{I}(1)$ & $\mathrm{I}(0)$ & $\mathrm{I}(1)$ & $\mathrm{I}(0)$ & $\mathrm{I}(1)$ \\
\hline 4 & 2.45 & 3.52 & 2.86 & 4.01 & 3.74 & 5.06 \\
\hline
\end{tabular}

Note: Critical values are based on the study of Pesaran et. al. (2001).

F-statistic is compared with the high and low values reported by Pesaran (2001) and at 5\% level of significance, $\mathrm{I}(1)$ is above the critical value. This indicates that there is a co-integration relationship between variables. With the existence of a co-integration relationship confirmed, I analyze the long and short term effects separately.

Long term coefficients are calculated with the following model:

$$
\begin{aligned}
\text { dollarization }=\beta_{0}+ & \beta_{1} \sum_{i=1}^{q} \text { dollarization }_{t-i}+\beta_{2} \sum_{i=0}^{p} \text { exratevolatility }_{t-i}+\beta_{3} \sum_{i=0}^{r} \text { interesteur }_{t-i}+ \\
& \beta_{4} \sum_{i=0}^{m} \text { interesttry }_{t-i}+\beta_{5} \sum_{i=0}^{n} \text { interestus }_{t-i}+\varepsilon_{t}
\end{aligned}
$$

Optimal lag length for ARDL model has been selected as ARDL $(1,0,0,0,0)$ using AIC information criteria. Table 5 demonstrates ARDL $(1,0,0,0,0)$ model estimation results and long term coefficient estimations.

Table 5. ARDL $(1,0,0,0,0)$ Model Estimation Results and Long Term Coefficients

\begin{tabular}{lllll}
\hline \multicolumn{1}{c}{ Variables } & \multicolumn{2}{c}{ ARDL(1,0,0,0,0) Model } & & \\
Coefficient & Standard Error & t-Statistic & Prob. \\
\hline DOLLARIZATION(-1) & 0.978167 & 0.015814 & 61.85514 & 0.0000 \\
EXRATEVOLATILITY & -2.885137 & 3.042389 & -0.948313 & 0.3437 \\
LINTERESTEUR & 0.007442 & 0.003689 & 2.017173 & 0.0445 \\
LINTERESTTRY & 0.023217 & 0.009915 & 2.341464 & 0.0198
\end{tabular}




\begin{tabular}{|c|c|c|c|c|}
\hline LINTERESTUSD & -0.004034 & 0.004963 & -0.812753 & 0.4170 \\
\hline C & -0.016477 & 0.009675 & -1.703095 & 0.0895 \\
\hline \multicolumn{5}{|c|}{ Long Term Coefficients } \\
\hline Variables & Coefficient & Standard Error & t-Statistic & Prob. \\
\hline EXRATEVOLATILITY & -0.132147 & 0.118510 & -1.115069 & 0.2657 \\
\hline LINTERESTEUR & 0.340851 & 0.200523 & 1.699808 & 0.0901 \\
\hline LINTERESTTRY & 1.063388 & 0.522111 & 2.036709 & 0.0425 \\
\hline LINTERESTUSD & -0.184772 & 0.124512 & -1.483972 & 0.1388 \\
\hline C & -0.754706 & 0.568651 & -1.327185 & 0.1854 \\
\hline R-squared & 0.953521 & \multicolumn{2}{|c|}{ Akaike info criterion } & -5.870605 \\
\hline F-statistic & 1312.975 & \multicolumn{2}{|c|}{ Schwarz criterion } & -5.800907 \\
\hline Prob(F-statistic) & 0.000000 & \multicolumn{2}{|c|}{ Durbin-Watson stat } & 2.066111 \\
\hline
\end{tabular}

Results of the ARDL model estimation indicates that in the long term, only interesteur and interesttry series has a statistically significant and positive effect on dollarization. Series of interestus and exratevolatility has no statistically significant effect on the dollarization in the long term. Results are in line with some of the relevant studies in the literature such as the study of Bahmani et.al. (2018) or Mengesha \& Holmes (2013).

Similar to the method used for the long term relationship coefficients, an error correction model based on ARDL approach has been used for short term relationship coefficients. In this model, the error correction coefficient (ECt-1) is expected to be lower than the magnitude of 1 , negative and statistically significant. Error correction coefficient represents the amount of correction to short term imbalances in the long term.

Short term coefficients are calculated with the following model:

$$
\begin{gathered}
\Delta \text { forexrate }_{=} \beta_{0}+\beta_{1} \sum_{i=1}^{q} \Delta \text { forexrate }_{t-i}+\beta_{2} \sum_{i=1}^{q} \Delta \text { volar }_{t-i}+\beta_{3} \sum_{i=1}^{q} \Delta \text { interesteur }_{t-i}+ \\
\beta_{4} \sum_{i=1}^{q} \Delta \text { interestry }_{t-i}+\beta_{5} \sum_{i=1}^{q} \text { interestus }_{t-i}+\alpha E C M_{t-i} \varepsilon_{t}(3)
\end{gathered}
$$

Using this model, short term model estimation results are reported in Table 6.

Table 6. ARDL Model Error Correction Model Estimation Results

\begin{tabular}{lllll}
\hline Variable & Coefficient & Std. Error & t-Statistic & Prob. \\
\hline D(EXRATEVOLATILITY) & -2.885137 & 3.042389 & -0.948313 & 0.3437 \\
D(LINTERESTEUR) & 0.007442 & 0.003689 & 2.017173 & 0.0445 \\
D(LINTERESTTRY) & 0.023217 & 0.009915 & 2.341464 & 0.0198 \\
D(LINTERESTUSD) & -0.004034 & 0.004963 & -0.812753 & 0.4170 \\
CointEq(-1) & -0.021833 & 0.001581 & -13.80962 & 0.0000 \\
\hline
\end{tabular}

According to the short term estimation results, interesteur and interesttry variables have a positive and statistically significant effect on the dollarization. In contrast, interestusd and 
exratevolatility have no statistically significant effect on dollarization. Error correction coefficient is negative and below the magnitude of 1 . This translates to, approximately $2 \%$ of shocks in the short term is corrected in the long term each period (1 week). In approximately 1 year or 50 weeks to be exact, all the effects of short-time shocks will have disappeared in the long term.

\section{Conclusion}

Findings from the analysis indicate that the volatility of the USD exchange rate has little effect on the dollarization in both the short and the long term. The interest rates of, however, have a significant effect on dollarization in both the short and the long term. In the long run, this effect is significantly amplified further. These findings collectively support that, the dollarization of deposits do not take place as a speculative response to daily fluctuations, but rather takes place as an offset mechanism to hedge money against the depreciation of the domestic currency.

In terms of magnitude, the interest rate of TRY has the most influential effect on dollarization. In their decision to dollarize their deposits, residents are influenced primarily by TRY interest rate, followed by EUR interest rate while the USD interest rate has little effect. The influence of TRY in this decision is approximately 3 times stronger than that of EUR interest rate. This suggests that, as long as the loss of value in the exchange rate is compensated by interest rate by the central bank, residents are willing to stay in or switch back to the Turkish Lira.

Conclusively, the main cause of dollarization in deposits and unilateral transfers abroad by the residents of Turkey is not the exchange rate or the volatility of the exchange rate, but rather the difference between interest rates of the foreign and domestic currency. In the short term, which is a time of high volatility, the decisions of the resident cannot be patterned effectively while in the long term, residents decide their positions mainly based on the interest rate announcements of the Central Bank of the Republic of Turkey. It can be argued that the best retaliation mechanism that the Central Bank of the Republic of Turkey can use against the exchange rate shocks, maybe through creating counter-shocks in the policy rate.

\section{References}

Bahmani-Oskooee, M., Halicioglu, F., \& Mohammadian, A. (2018). On the asymmetric effects of exchange rate changes on domestic production in Turkey. Economic Change and Restructuring, 51(2), 97-112.

Clarida, R., \& Gali, J. (1994). Sources of real exchange-rate fluctuations: How important are nominal shocks? 41, 1-56. Elsevier.

Dinçer, H., Hacıŏglu, Ü., \& Yüksel, S. (2018). Determining Influencing Factors of Currency Exchange Rate for Decision Making in Global Economy Using MARS Method. In Geopolitics and Strategic Management in the Global Economy (pp. 261-273). IGI Global.

Farrant, K., \& Peersman, G. (2006). Is the exchange rate a shock absorber or a source of shocks? New empirical evidence. Journal of Money, Credit, and Banking, 38(4), 939-961.

Lastrapes, W. D. (1992). Sources of fluctuations in real and nominal exchange rates. The Review of Economics and Statistics, 74(3), 530-539. 
Lay, S. H., Kakinaka, M., \& Kotani, K. (2012). Exchange rate movements in a dollarized economy: The case of Cambodia. ASEAN Economic Bulletin, 65-78.

Mengesha, L. G., \& Holmes, M. J. (2013). Does Dollarization Alleviate or Aggravate Exchange Rate Volatility? Journal of Economic Development, 38(2), 99.

Neanidis, K. C., \& Savva, C. S. (2009). Financial dollarization: Short-run determinants in transition economies. Journal of Banking \& Finance, 33(10), 1860-1873.

Pesaran, M. H., Shin, Y., \& Smith, R. J. (2001). Bounds testing approaches to the analysis of level relationships. Journal of Applied Econometrics, 16(3), 289-326.

Rossi, M. M., \& Leigh, M. D. (2002). Exchange rate pass-through in Turkey. International Monetary Fund.

Shin, Y., Yu, B., \& Greenwood-Nimmo, M. (2014). Modelling asymmetric cointegration and dynamic multipliers in a nonlinear ARDL framework. In Festschrift in honor of Peter Schmidt (pp. 281-314). Springer.

TCMB - Financial Accounts Report. (n.d.). Retrieved May 26, 2019. 